zoologist as well as the specialist in fish physiology". I think it will, and I expect that it will be found in all relevant libraries, in spite of the heavy price that has to be paid.

C. E. LuCAS

\section{NEW WORLD FLORA}

\section{Vascular Plants of the Pacific Northwest}

Part 1: Vascular Cryptogams, Gymnosperms, and Monocotyledons. By C. Leo Hitchcock, Arthur Cronquist, Marion Ownbey and J.W. Thompson, Pp. 914. (University of Washington Press: Seattle and London, November 1969.) $238 s ; \$ 25$.

THE recent publication of part one now completes this magnificent and already well known flora, the other four parts (each worthy of being called a volume) having appeared in reverse order during the past fifteen years, starting with Cronquist's Compositae.

The Pacific North.West, as defined by the authors of the flora, is an extensive area of territory covering the states of Washington, northern Oregon, Idaho north of the Snake River plains, the western mountainous part of Montana and southern British Columbia. Some 4,000 species of vaseular plants are known to be indigenous here or to have been introduced and these have now been fully dealt with in the five parts. As the title indicates, part one includes the vascular cryptogams (ferns and fern allies), gymnosperms and monocotyledons, most of them dealt with by the senior author C. L. Hitcheock. Users of this and probably the other parts of the flora may possibly be confused by the circumscription and nomenclature of the divisions and classes of the higher plants. For instance, here the name Pinophyta is used for Gymnospermae, Magnoliophyta for Angiospermae and Liliatae for Monocotyledonae, following the recent proposals of Cronquist et al. in Taxon, 15, 1966. The sequence of monocotyledon families also follows Cronquist's Evolution and Classification of Flowering Plants (1968) and might seem strange to those not already familiar with this treatise. Besides the usual keys to families, genera and species and rather full descriptions, complete "regional" synonymy is given together with details of chromosome number (very frequently known), "genuine" vernacular names and information on distribution and ecology. Finally, notes on infraspecific variation have been added. Following the (unfortunate?) tradition of most temperate floras, no matter how elaborate, no specimens are, however, cited other than type material.

Perhaps two features above all contribute to the usefulness of this particular part. The first of these is the excellence of the illustrations by J. R. Janish. Practically every species has been illustrated by simple but extremely clear and accurate line drawings, depicting habit and diagnostic characteristics. The second is the inclusion of special keys. One to the grasses of the area (again illustrated) is based purely on vegetative features and will be of great potential use to pasture ecologists and agriculturists who so often must, of necessity, identify sterile material. There is also a key to aquatic plants (all vascular groups included), again chiefly on vegetative characters.

This volume, being the last and largest part of the flora to appear, includes several sections relating to the work as a whole. There is, for instance, an index to all the plant families, a glossary and a corrigendum to the other parts. Finally, there is a complete index to vernacular, generic and specific names.

The sheer bulk of this flora means that it will serve chiefly as a work of reference, but the thoroughness of its production will certainly ensure for it a status and value far above that of a mere regional flora, for many years to come.

Brian T. Styies

\section{QUANTUM CHEMISTRY}

\section{Methods of Molecular Quantum Mechanics}

By R. McWeeny and B. T. Suteliffe. (Theoretical Chemistry-A Series of Monographs, Vol. 2.) Pp. ix +307. (Academic Press: London and New York, December 1969.) $84 s ; \$ 13.50$.

WRITTEN for a far more sophisticated and exacting readership than the first volume in the series, this is a book in which even the most experienced quantum chemist should find a great deal of value. A rigorous yet economical exposition, characterized throughout by refreshing critical insight, it has all the qualities one would expect of its authors.

Being designed "for students specializing in theoretical chemistry or molecular physics", it uses techniques which go well beyond the repertoire of the average chemist. It is certainly a work of consolidation rather than primary instruction. At first sight, much of the analysis will seem formidable to student readers; and, while those who do battle with the difficulties will find themselves very well rewarded, I think this book will probably be more popular with teachers of quantum chemistry than with their students.

Together with two appendices, the first two chapters present a brisk survey of the general principles and theorems of wave mechanies, illustrated by reference to one- and two-electron systoms. Next comes a careful account of the various operators used in formulating many. electron antisymmetrized wave functions.

Having completed the usual preliminaries (though by no means always in the usual way), the authors then provide a most welcome discussion of electronic charge distribution, including, of course, a description of density matrices.

The next three chapters deal in turn with the HartreeFock theory and its principal elaborations, with valencebond theory, and with various recent developments (generalized product functions; variation-perturbation theory for group functions; cluster development; correlated pair functions).

A chapter on electrical and magnetic effects is supplemented by a quite substantial appendix dealing with relativistic terms in the Hamiltonian operator.

The book concludes with a description of some typical molecular calculations. This is the only chapter in which any numerical results are discussed.

It could perhaps be argued that much of the material in this book could have been expounded accurately and effectively in a simpler way; but this was clearly not the authors' intention, and they are to be congratulated on producing a contribution to the didactic literature of quantum chemistry that is really distinctive.

\section{E. Theal Stewart}

\section{Obituaries}

\section{Dr Peyton Rous}

Experimental pathology and cancer research, and indeed the whole of biological and medical science, have sustained immonse loss from the death, on February 16 , 1970, of Francis Peyton Rous, at the age of 90 . His special fields will never be the same without him. Yet our main emotion must be of gratitude for his long life and epochal contribution.

Rous's mother was descended from Huguenots who had settled in Virginia after the Edict of Nantes; and his father was a Baltimorean of English forebears. Reading of his early life evokes and recaptures in remarkable degree the spirit of a great period in the history of the United States and. a little later, that of an outstanding 
phase in American medicine during the early years of the century. After graduating MD at the Johns Hopkins Medical School in 1905, Rous's intercsts very early turned to research, with a period at Ann Arbor under Warthin and later in the Rockefeller Institute, New York, where he spent the groat part of his working life in the most happy and congenial of conditions. His move to the Rockefeller was a stroke of genius on the part of Simon Flexner, who accorded him complete freedom and every encouragernent, a privilege which Rous thenceforth ever valued and later recorded on many occasions.

Between 1907 and 1910 Rous made a wonderful start, with papers on lymphocyte physiology, hacmatology, the corebrospinal fluid and tissue transplantation. Very soon there came the stroke of fate. In the words of $\mathrm{O} . \mathrm{H}$. Robertson, "One day a chicken fancier came in to Rous's laboratory bringing a fowl with a large lump on its leg. Concerned for his flock, this man had taken the fowl to several unresponsive pathologists. Rous saw that the lump was a tumour and in a class of animals unstudicd in such relation". The tumour proved to be a spindle-cell sarcoma, which Rous was able to transmit to other fowls of the same inbred stock, not only by grafting but also through the injection of cell-free filtrates. The times must have been propitious, following Ellermann and Bang's description of an apparent leukaemia virus in 1908; yet Rous's discovery was a monumental and key event in the history of cancer research.

The Rous agent, as it camc to be called, also seemed to be viral in nature, with extraordinary specificity in transforming normal cells into the exact replica of the sarcoma colls from which it was derived. Later, Rous and his co-workers uncovered other avian oncogenic viruses, each again with its own individual transforming property. Especially with J. B. Murphy, Rous studied the growth of such tumours and viruses in the avian cmbryo, perhaps the earliest use of this technique, and an example of the freshness and originality which characterized so much of his work and still exert their influence.

There is evidence that these discoveries wero not perhaps fully appreciated at the timo, as was seen from a species of metaphysical pathology on the part of the orthodox, according to which the tumours, although sarcomata, could not be tumours since they were virus-induced. Rous was also disappointed by his failure, after strenuous efforts, to demonstrate any kind of viral transmission of canccr in mammals. For some fifteen years he then spent his energies in more physiological pursuits, and this period embraced a wide variety of classical papers. Outstanding topics woro the preservation and transfusion of blood, with practical application in both tho First and Second World Wars by moans of the Rous-Turner formula; the genesis of gallstones and the relation of blood destruction to bile pigment output; liver function in many aspects; and the measurement of hydrogen ion concentration in living tissues. Throughout his work Fious showed rurc technical ingenuity, porhaps the most famous instance being his isolation of Kupffer cells in pure culture by loading them with particulate iron and collect. ing them from liver perfusatos with the aid of a magnet. Another instance ahead of its time was his plating mothod for individual cells.

Rous's wholehearted and enthusiastic return to the cancer ficld was prompted by two personal episodes. A few years before, W. E. Gye had made certain claims as to the constitution of the Rous agent. Although these claims were not confirmed, their investigation had the undoubted effect of bringing the filterable sarcomata into a new promincrice, and through this development Rous was both encouraged and stimulated - something for which he always expressed much gratitude. Secondly, the late Richard E. Shope had persuaded Rous to embark on a full-scale investigation of the so-called Shope rabbit papilloma virus recently discovered in the cottontail rabbit. Hence it came that Rous entered a quite new

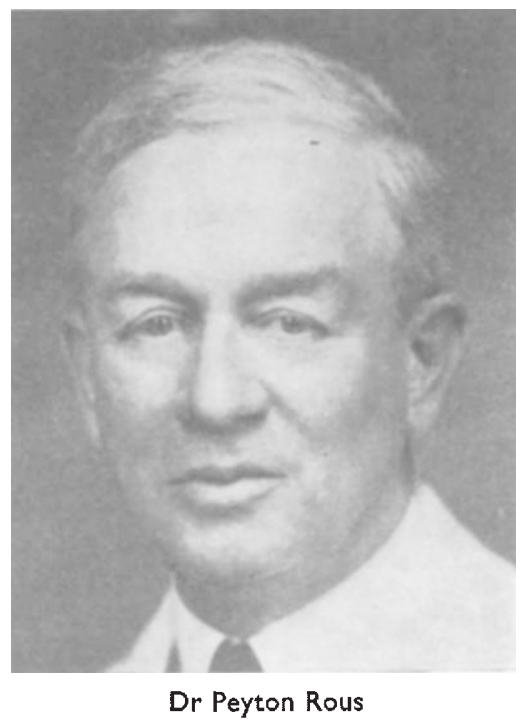

and highly productive phase which endured to the end of his life. Of special and lasting value were his studies of the biological interactions between chemical carcinogens and neoplastic viruses, and the generation of highls malignant carcinomata in the rabbit on the basis of the viral papillomas. In part, this experimental work led to. and was intertwined with, a fundamental conception (with Friedewald) which ranks, in the viow of many, as perhaps the most profound of Rous's contributions; namely, the dissection of the carcinogenie process into two main stages of initiation and promotion. Independently advocated by Berenblum, the hypothesis remains influential and may still receive its explanation in chemical and cytological terms.

At the time of the discovery of the avian tumour viruses, and for several docades thereafter, technical resources were inddcquats to penetrate their structure and biochemistry. Although much remains to be done, great advances are in prospect which might dramatically on even decisively illumino the whole of the cancer problem. Meantime, in his later years hous expcrienced great excitement from many discoveries on the part of others demonstrating the unexpected quality of the Rous virus, enhanced or in association with other agents, to break the species barrier and to evoke tumours in many species. both avian and mammalian; and secondly, from the immense resurgence of tumour virology to which his lone observation of 1910 had pointed the way.

Aside from his own publications (some 300 in all) Rous also contributed to scientific presentation and acted as editor of the Journal of Experimental Medicine for over thirty years. His width of cultivation could also be seen in most amusing and lighthearted nssays, as on tactless. ness, and the lamentable dccline in self-satisfaction. Honours descended upon him from every part of the new world and tho old, culminating in the Nobel Prize fo: Medicine (jointly) in 1966. For many reasons of domesticity and frichdship he had special ties of affection for England and, with much other recognition, treasured his Linacre lectureship at Cambridge, his honorary fellowship of 'Trinity Hall, the Walker Prizo of the Royal College of Surgeons, and his foreign membership of the Foyal Society. In admiration he would rofer to "those wonderful powder-blue volumes" (the Scientific Reports) of tho Imperial Cancer Research Fund.

Rous was a true worker at the bench, yet believed that the experimental pathologist and the artist have much in common. He described his recreation as "relishing life". and this he did to the full. When the history of cancer research comes to be written, he will rank with the highest in honour. 